\title{
Leaf anatomy of the South African Danthonieae (Poaceae). XVII. The genus Chaetobromus
}

\author{
R.P. ELLIS*
}

Keywords: Chaetobromus, Danthonieae, leaf anatomy, Poaceae

\section{ABSTRACT}

The leaf anatomy of Chaetobromus Nees is described and illustrated. The genus has non-Kranz anatomy but with a low lateral cell count. The abaxial epidermis is not pooid as microhairs are present, the silica bodies are dumbbell-shaped and the stomatal subsidiaries are dome-shaped. From the sample of 33 randomly selected specimens from throughout the distribution range of the genus it was possible to identify four anatomical groups, each associated with a specific habitat and differing in vegetative morphology. These intergrade in a reticulate pattern and do not constitute discrete entities. It appears that the genus is monospecific with four poorly separated subspecific taxa.

\section{UITTREKSEL}

Die blaaranatomie van Chaetobromus Nees word beskryf en geillustreer. Die genus het nie-Kranzanatomie maar met 'n lae laterale seltelling. Die abaksiale epidermis is nie pooied nie aangesien mikrohare aanwesig is, die silikaliggame murgbeenvormig en die hulpselle van die huidmondjies koepelvormig is. Uit 'n monster van 33 eksemplare wat willekeurig vanuit die hele verspreidingsgebied van die genus gekies is, kon vier anatomiese groepe geidentifiseer word, elk met 'n spesifieke habitat geassosieer, en verskillend wat vegetatiewe morfologie betref. Hierdie groepe vloei ineen in 'n netvormige patroon en vorm nie afsonderlike entiteite nie. Dit blyk dat die genus monospesifiek is met vier swak omgrensende subspesifieke taksons.

\section{INTRODUCTION}

Chaetobromus Nees is a small genus in which four closely allied species have been described. However, they are very difficult to distinguish from one another and must be regarded as provisional until the genus has been studied in greater detail. Nowadays only three specific names are generally accepted (Clayton \& Renvoize 1986). These are $C$. dregeanus Nees, $C$. involucratus (Schrad.) Nees and $C$. schraderi Stapf. The name $C$. schlechteri Stapf, that of the fourth species described, has fallen into disuse although it is correct (Smook \& Gibbs Russell 1985). Chippindall (1955) does not consider $C$. schlechteri to be distinct from $C$. dregeanus.

Chaetobromus is indigenous to southern Africa with the centre of distribution in the western Cape, Namaqualand and southern South West Africa/Namibia. The genus occurs mainly in the Strandveld, the Namaqualand Coast Belt of the Succulent Karoo and the Namaqualand Broken Veld (Acocks 1975). All these veld types are at low altitudes, with sandy soil and with winter rainfall decreasing northwards. It is also occasionally found further south in the southern Strandveld as far south as Table Bay. It is of interest that Chaetobromus also occurs at higher altitudes in the Western Mountain Karoo from Loeriesfontein southwards to Sutherland. It is rare in this latter veld type but this appears to be due to overgrazing.

The leat anatomy of Chaetobromus has received little attention in the literature. De Wet (1956) reported that

\footnotetext{
* Botanical Research Institute, Department of Agriculture and Water Supply, Private Bag X101. Pretoria 0001.

MS received: 1987.10 .20 .
}

the epidermis is panicoid, with linear microhairs and dumbbell-shaped silica bodies, and the mesophyll is 'festucoid' with a poorly differentiated outer bundle sheath and uniformly distributed chlorenchyma. Watson et al. (1986) give further anatomical details. They consider the silica bodies to be intermediate between the panicoid and the pooid type. Stomata are present with guard cells flush or overlapping the interstomatals and the subsidiary cells are either parallel-sided or low domeshaped - either panicoid or pooid. These authors also did not observe abaxial microhairs. They consider the genus to be $C_{3}$ although the lateral cell count is rather low. The midrib is structurally indistinguishable from the other larger bundles. All bundles have wide adaxial bundle sheath extensions. The bulliform cells occur in very large, simple, fan-shaped groups without associated colourless cells. The present paper will describe and illustrate the anatomy of the genus based on a representative sample and will compare this anatomy with the findings of the above authors.

\section{MATERIALS AND METHODS}

Leaf blade segments of Chaetobromus plants were freshly fixed in the field in FAA (Johansen 1940). Herbarium voucher specimens from the same plants were taken for determination by the National Herbarium (PRE) where they are housed.

Leaf transverse sections, $10 \mu \mathrm{m}$ thick, were prepared after desilicification in hydrofluoric acid (Breakwell 1914), dehydration using the method of Feder \& O'Brien (1968) and embedding in Tissue Prep (Fischer Scientific). These sections were stained in safranin and fast green (Johansen 1940). The manual scraping method of Metcalfe (1960) was used to prepare scrapes of the abaxial 


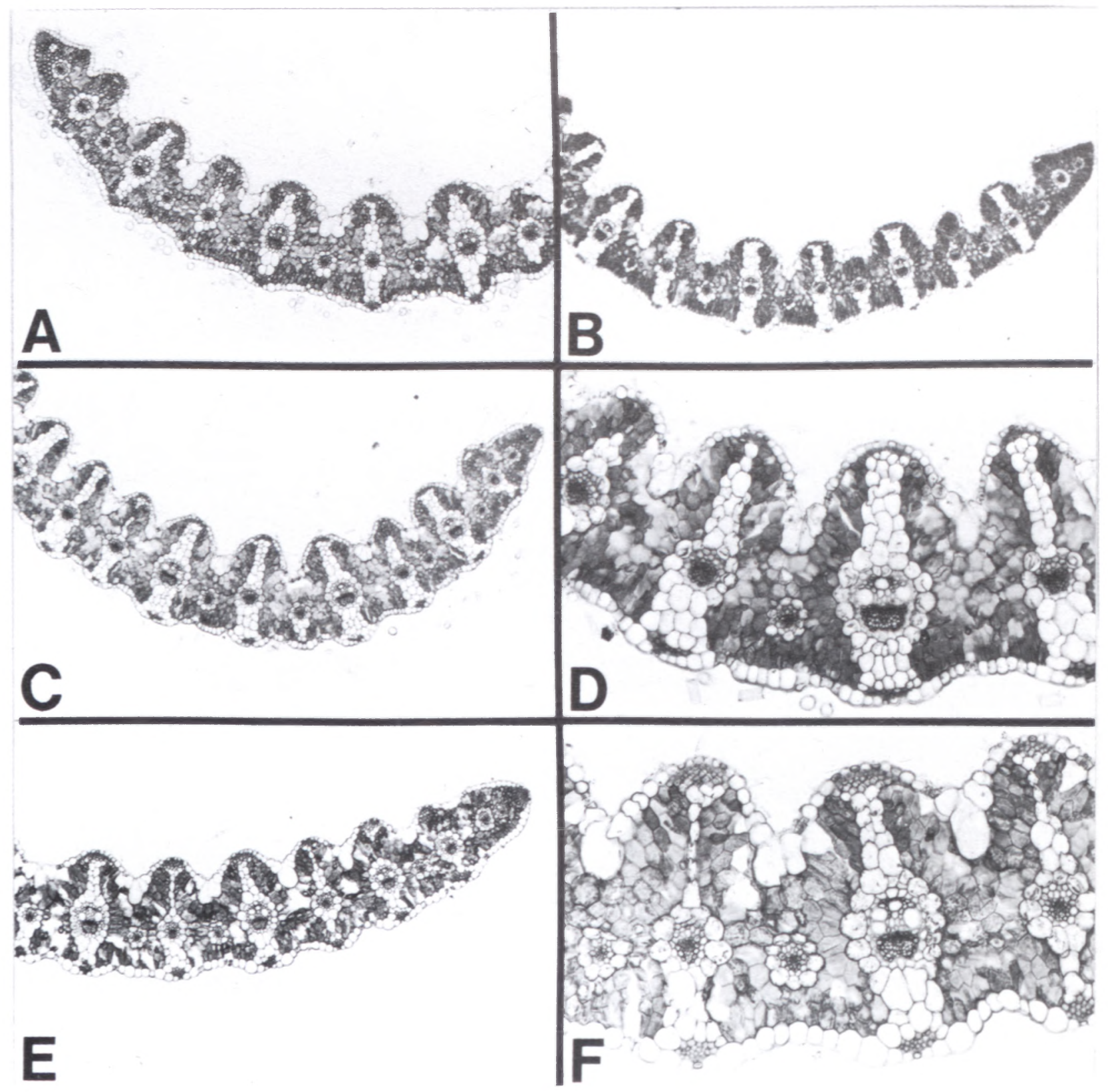

FIGURE 1. - Leaf blade anatomy of Chaetobromus specimens representative of Group 1 as seen in transverse section. A, outline showing sectioned macrohairs, Ellis 2182, X 100. B, slightly inrolled outline, Ellis 2187, X 100. C-D, Ellis 2184: C, leaf outline, $\mathrm{X} 100 ; \mathrm{D}$, anatomical detail of chlorenchyma and vascular bundles with abaxial macrohairs, $\times 250$. E-F, Ellis 2176: E, outline of margin, $\times 100 ; \mathrm{F}$, detail of chlorenchyma with low lateral cell count, $\times 250$.

leaf epidermis. The anatomical structure was recorded photographically using a Reicherdt Univar microscope and Ilford Pan F Film (50 ASA).

The standardized terminology of Ellis $(1976,1979)$ was used for the anatomical descriptions. The following abbreviations will be used in these descriptions:

$$
\begin{aligned}
& \mathrm{vb} / \mathrm{s} \text { - vascular bundle/s } \\
& \text { 1'vb/s - first order vascular bundle/s } \\
& \text { 2'vb/s - second order vascular bundle/s } \\
& \text { 3'vb/s - third order vascular bundle/s } \\
& \text { ibs - inner bundle sheath; mestome sheath } \\
& \text { obs - outer bundle sheath; parenchyma sheath }
\end{aligned}
$$

Identification of the voucher specimens to species level proved to be very difficult and unsatisfactory. This is understandable as the genus is in need of revision (Chippindall 1955), the species concepts are vague, and species are indistinct and intergrade, with many intermediate specimens being present. It has, therefore, been decided to consider this genus at the generic level only. Separate descriptions of the species will not be given due to uncertainty of the exact identity of a significant proportion of the voucher specimens. The anatomical description of the genus given is inclusive of the entire sample of 33 specimens used in this study.

It was, nevertheless, possible to sort the material studied into four informal groups using anatomical, ecological and vegetative morphological criteria. These informal groups appear to correspond reasonably well with the species described in the genus and they will be compared and contrasted in an attempt to ascertain whether they represent distinct species. In the citation of the specimens examined these informal groups are used together with their probable specific equivalent. Asterisks indicate cases where there is a discrepancy between the herbarium determination (in brackets) and the grouping used here. 


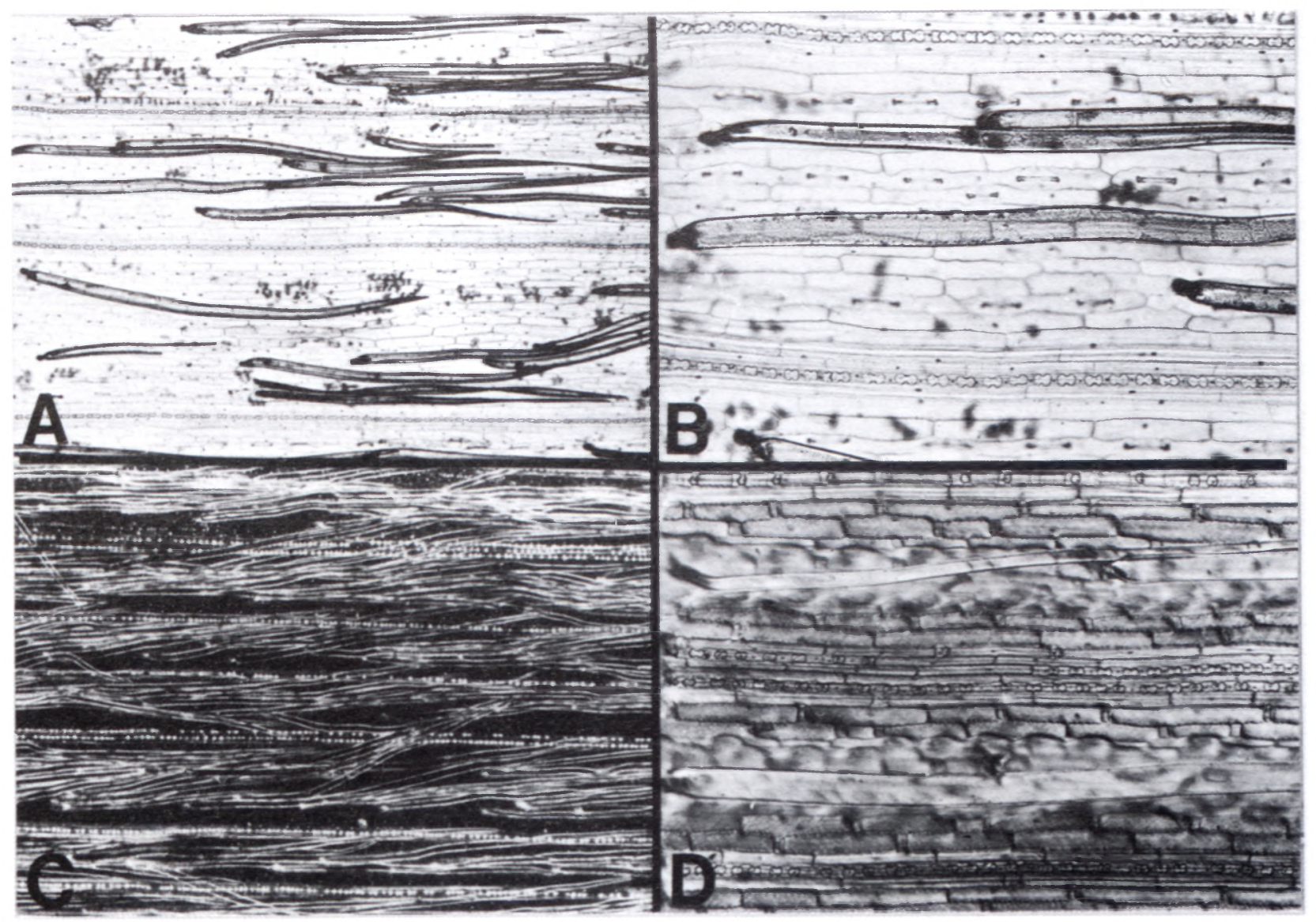

FIGURE 2. - Abaxial epidermal structure of Chaetobromus specimens of Group 1 as seen in surface view. A-B, Ellis 2175; A, macrohairs, many filled with air, $\times 160$; B, detail of macrohair bases and silica bodies, $\times 250$. C, pubescence of leaf surface, phase contrast, Ellis $2187, \times 100$. D, macrohairs, silica bodies and intercostal microhairs, Ellis $2184, \times 250$.

\section{Specimens examined}

\section{Group 1. Chaetobromus involucratus}

CAPE. - 2816 (Oranjemund): Richtersveld, Beesbank (-BC), Ellis 5071; Beauvallon (-DA), Ellis $2175^{*}, 2176^{*}$ (C. schraderi) 2916 (Port Nolloth): Port Nolloth (-BD), Ellis 2182, 2183, 2184, 2185, 2187. 3017 (Hondeklipbaai): Hondeklip Bay (-AD), Ellis 5344, 5345. 3217 (Vredenburg): St Helena Bay, Stompneusbaai (-DB), Ellis $703 *$ (C. schraderi).

\section{Group 2. Chaetobromus schraderi}

CAPE. - 2816 (Oranjemund): Richtersveld, Beesbank (-BC), Ellis 5073. 2917 (Springbok): Steinkopf (-BD), Ellis 2164, 2165, 2166; Spektakelberg, Sandhoogte Pass (-DA), Ellis 2191, 2192, 2193, 2194. 3018 (Kamiesberg): $43 \mathrm{~km} \mathrm{~N}$ of Bitterfontein (-CA), Ellis 1730* (C. dregeanus); Bitterfontein (-CC), Ellis 2206. 3118 (Van Rhynsdorp): $64 \mathrm{~km} \mathrm{~N}$ of Van Rhynsdorp (-BC), Ellis 1733* (C. dregeanus).

Group 3. Chaetobromus dregeanus (lowland form)

CAPE - 3218 (Clanwilliam): Elands Bay (-AD), Ellis 1691. 3317 (Saldanha): Saldanha Bay (-BB), Ellis 1696. 3318 (Cape Town): Yzerfontein $(-\mathrm{AC})$, Ellis 692; Blouberg Strand $(-\mathrm{CD})$, Ellis 2357, 2358.

Group 4. Chaetobromus dregeanus (mountain form)

CAPE. - 3019 (Loeriesfontein): Loeriesfontein at junction of Nieuwoudtville and Granaatboskolk roads $(-C D)$, Ellis 2422 $103 \mathrm{~km}$ from Brandvlei on road to Loeriesfontein (-DC), Ellis 2423, 2424. 3118 (Van Rhynsdorp): $10 \mathrm{~km} \mathrm{~S}$ of Bitterfontein ( $-\mathrm{AB})$, Ellis 2426. 3119 (Calvinia): Van Rhyns Pass (-AC), Ellis 2457; Botterkloof Pass between Calvinia and Clanwilliam $(-\mathrm{CD})$, Ellis 2450. 3220 (Sutherland): Sutherland $(-\mathrm{BC})$, Ellis 2467.

\section{LEAF ANATOMY OF THE GENUS CHAETOBROMUS}

\section{Leaf in transverse section}

Outline: open, expanded, flat (Figures 3A-C, 5A \& B) to slightly inrolled (Figures 1A-C, 5D) or narrow, infolded (Figure 7A, C, G \& H) or inrolled (Figure 7E); leaf thickness 230-550 $\mu \mathrm{m}$. Ribs and furrows: slight (Figure 3A-D) to medium (Figure $1 \mathrm{~A}-\mathrm{F}$ ) rounded adaxial ribs overlie 1'vbs and 2'vbs; furrows shallow and wide (Figure 3A-D) to narrow, cleft-like (Figure 7E \& F); furrows may be present over 3'vbs; slight abaxial ribs and furrows sometimes present (Figures $1 \mathrm{~A}-\mathrm{F}, 7 \mathrm{H}$ ), usually not developed. Median vascular bundle: not structurally distinct from lateral l'vbs. Vascular bundle arrangement: tends to be variable and rather irregular although a basic pattern is discernible; $5,7,9$ or 11 l'vbs in leaf section; one 2'vb between consecutive l'vbs although this sometimes varies; one 3'vb between adjacent 1 'vbs and 2'vbs but may be absent but then usually only on one side of each 2'vb (Figures 1F, 3E \& 5C). All vbs situated in centre of blade. Vascular bundle description: 1 'vbs round to elliptical in shape; phloem adjoins ibs; metaxylem vessels very narrow, diameters much less than those of obs cells (Figures 1D \& F, 3D \& F, 5E \& F); 2'vbs and 3'vbs round to elliptical; xylem and phloem distinguishable. Vascular bundle sheaths: double; obs round to elliptical; prominent adaxial and abaxial multiseriate parenchymatous extensions extend to the 
upper and lower epidermis from all 1'vbs (Figures 1D \& F, 3D \& F, 5E \& F, 7B, D \& F); 2'vbs with narrower adaxial extensions, being bi- or uniseriate; 3'vbs with irregular extensions or extensions absent; obs cells inflated, round, the cells smaller than the mesophyll cells; walls thin; either translucent, without chloroplasts (Figures 3D \& 7F) or with small chloroplasts, fewer than in the chlorenchyma cells (Figures 1D \& F, 3E \& F, 5C \& E); ibs entire, of small lignified cells, those opposite the phloem with the inner tangential and radial walls thickened (Figures 3D \& 5C). Sclerenchyma: minute adaxial and slightly larger abaxial strands associated with the 1'vbs and 2'vbs; no sclerenchyma adjacent to the 3'vbs; small sclerenchyma caps in the margins; cell walls not lignified. Chlorenchyma: irregular (Figure 5E \& F) to tending to radiate condition (Figures $1 \mathrm{D} \& \mathrm{~F}, 2 \mathrm{D}-\mathrm{F}$ ); more than one layer of radiating cells; lateral cell count low, from 3-5 cells; continuous between bundles; chlorenchyma cells large, angular and equidimensional (Figure 1D \& F) to elongated (Figure 3D-F); often nucleate and may be refractive under interference contrast (Figure 3F); no arm cells or fusoids; intercellular air spaces large and frequent. Colourless cells: absent except in the bundle sheath extensions. Adaxial epidermal cells: small to medium-sized bulliform groups at bases of furrows (Figures 1D \& E, 3D \& F, 5E \& F, 7F); occupy less than $1 / 4$ leaf thickness; central cell of ten largest and may be shield-shaped; cuticle very thin; epidermal appendages usually absent but macrohairs (Figure 1A) and prickles (Figure 5E) may be present; no papillae. Abaxial epidermal cells: bulliform cells absent; cuticle very thin or slightly thickened; macrohairs present (Figure 1A, C \& D) or absent; no prickles or papillae.

\section{Abaxial epidermis in surface view}

Intercostal long cells: elongate rectangular (Figures 2B \& D, 4C \& E, 8F) or fusiform (Figures 4D, 6A-D, $8 \mathrm{~A}-\mathrm{D}$ ); walls straight (Figures $2 \mathrm{~A}-\mathrm{D}, 4 \mathrm{~A}-\mathrm{E}$ ) to slightly sinuous (Figures 6A-F, 8A-F); cell shape and size consistent across individual intercostal zones; long cells adjoin one another or are separated by short cells; no bulliform cells. Stomata: low dome-shaped (Figures 2B \& D, 4C \& E) to dome-shaped (Figures 6B, D, F , 8A-F) subsidiary cells; occurring throughout intercostal zones

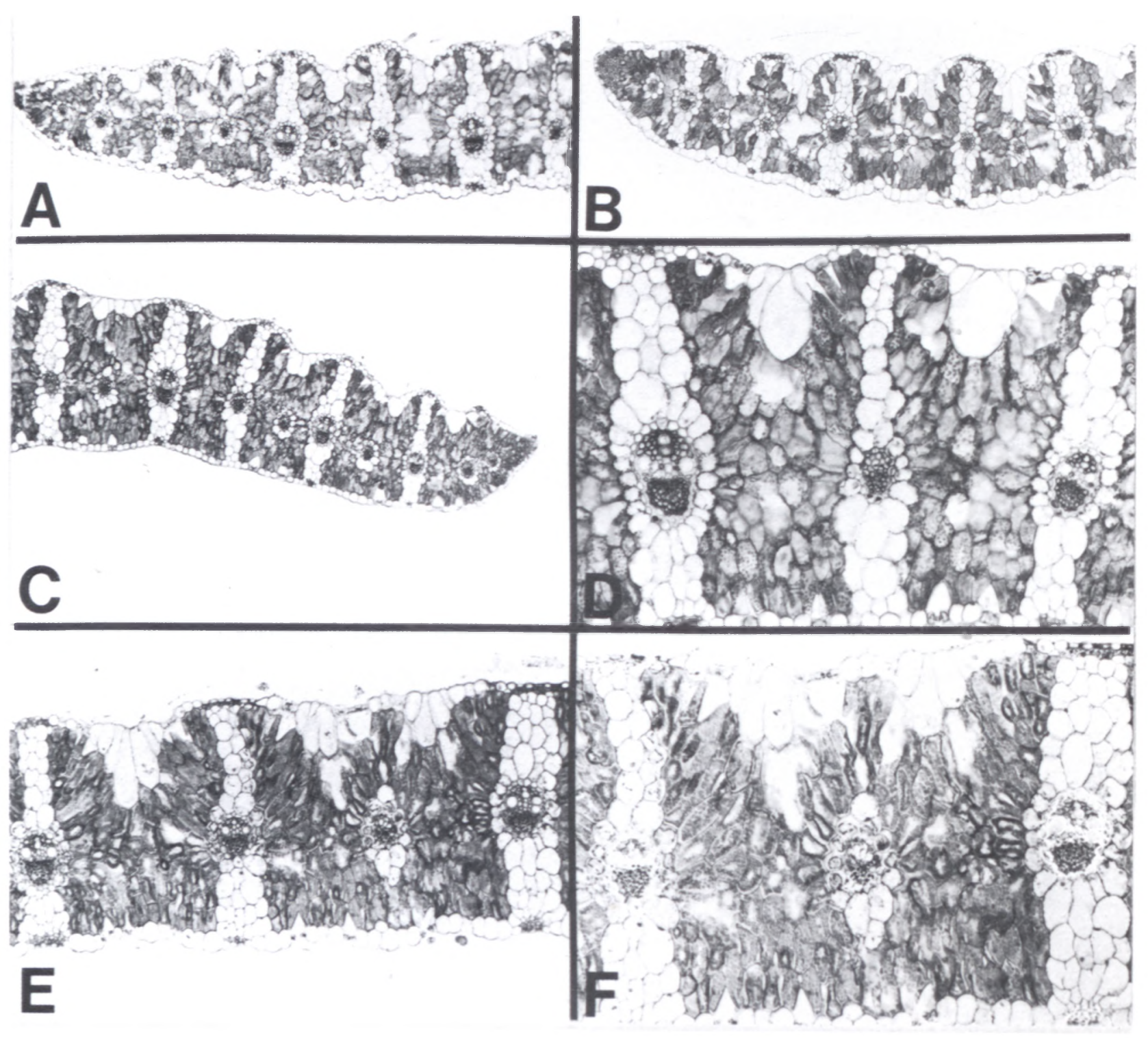

FIGURE 3.- Transectional leaf anatomy of Group 2 representatives of Cheetobromus. A, expanded, flat outline, Ellis 2165 , X 100. B, leaf margin, Ellis 2164, X 100. C-D, Ellis 2166: C, outline, X 100; D, chlorenchyma cell arrangement and vascular bundles with parenchymatous extensions, $\times 250$. E-F, Ellis 2191: E, vascular bundle arrangement, $\times 160 ; \mathrm{F}$, detail of chloroplasts in chlorenchyma and bundle sheath cells, interference contrast, $\times 250$. 
or restricted to two or four rows; stomata in files separated by single interstomatal long cell, this either short or elongated, more than three times longer than wide; tend to be overarched by inflated long cells (Figure 9F). Intercostal short cells: presence variable, either absent or irregularly present to present between all long cells; either single or paired; tall and narrow in shape. Papillae: absent. Prickles: absent except for very small hooks which are rarely present (Figure 6D). Microhairs: present or absent; elongated, basal and distal cells about equal in length (Figures 4C, 9H) or distal cell much shorter (Figure 9D); hairs short, about the same length as the stomata; distal cell deciduous and thin-walled. Macrohairs: usually absent but may be present (Figures $2 \mathrm{~A}-\mathrm{D}$, 9A, B); unicellular, hard, stiff and pointed; base constricted and superficial, not associated with specialized raised epidermal cells (Figures 9B, 10); appressed to leaf surface and visible in transections (Figure 1A, C \& D); length up to $120 \mu \mathrm{m}$; tend to be very numerous; lumens often filled with air (Figure 2A \& B); intercostal. Silica bodies: horizontally elongated, variable dumbbell-shaped (Figures 2B, 4E, 6B \& D, 8B, D \& F); rarely nodular (Figure 6F); exclusively costal; granules may be present.

\section{Adaxial epidermis in surface view}

Differs from abaxial epidermis in having shorter intercostal long cells, costal prickles with elongated barbs are common (Figure $9 \mathrm{C} \& \mathrm{G}$ ) and numerous microhairs are present adjacent to the costal zones (Figure 4F); the microhairs are larger and more common than on the abaxial surface; the distal cell may also be rounded and not tapering (Figure 9H). These differences in frequency of occurrence, size and shape of the adaxial and abaxial microhairs on the same leaf are unusual.

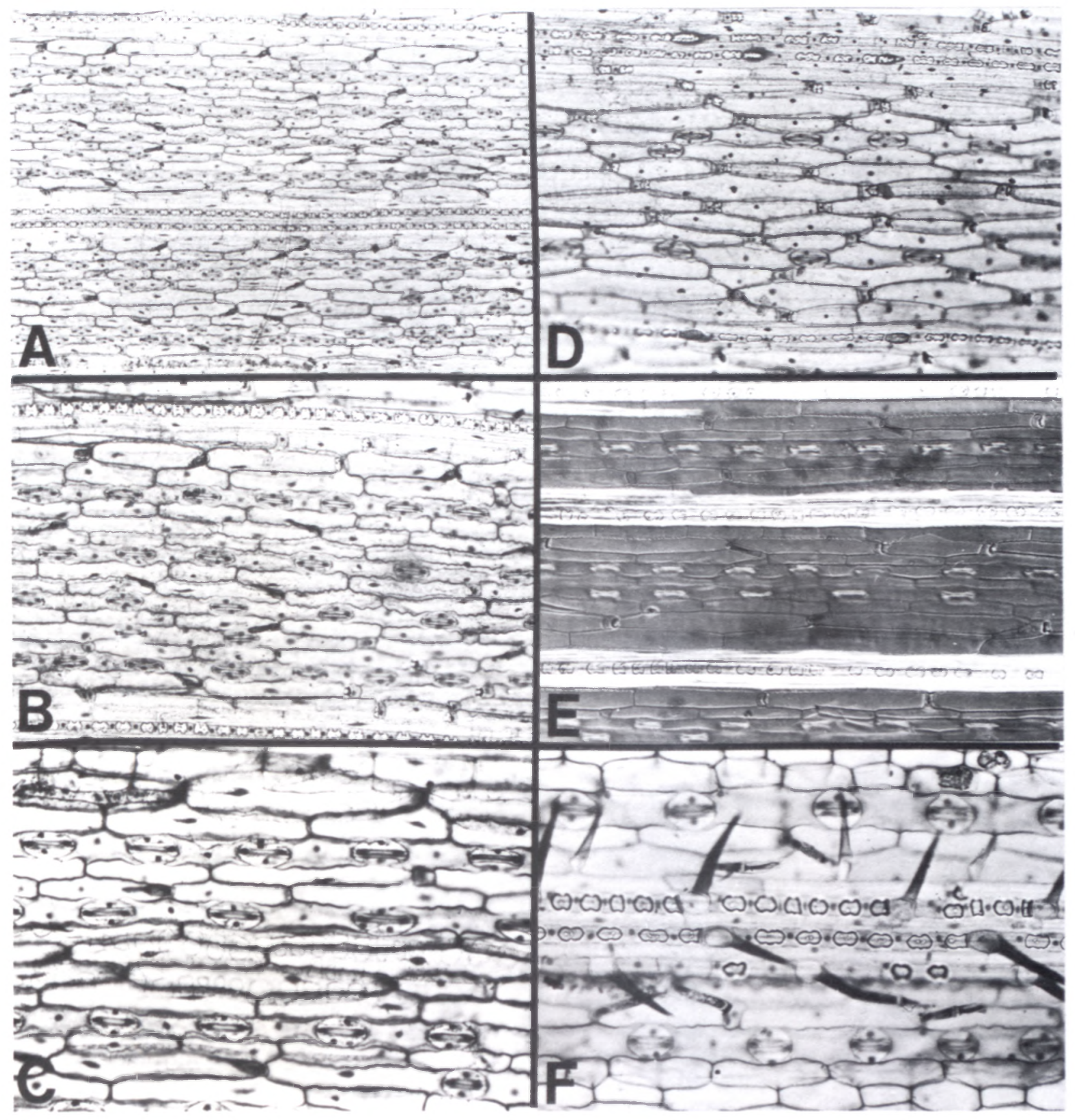

FIGURE 4.-A-E, abaxial epidermis of Group 2 Chaetobromus specimens: A-C, Ellis 2191: A, zonation pattern, $\times 160$; B, intercostal zone showing absence of macrohairs, $\times 250$; C, detail of subsidiary cell shape, intercostal long cells and microhairs, $\times 400$. D, fusiform intercostal long cells, Ellis 2164, X 250. E, interference contrast showing microhairs, Ellis 1730 , $\times 250$. F, adaxial epidermis showing prickle hairs and microhairs, Ellis 2206, X 400 . 


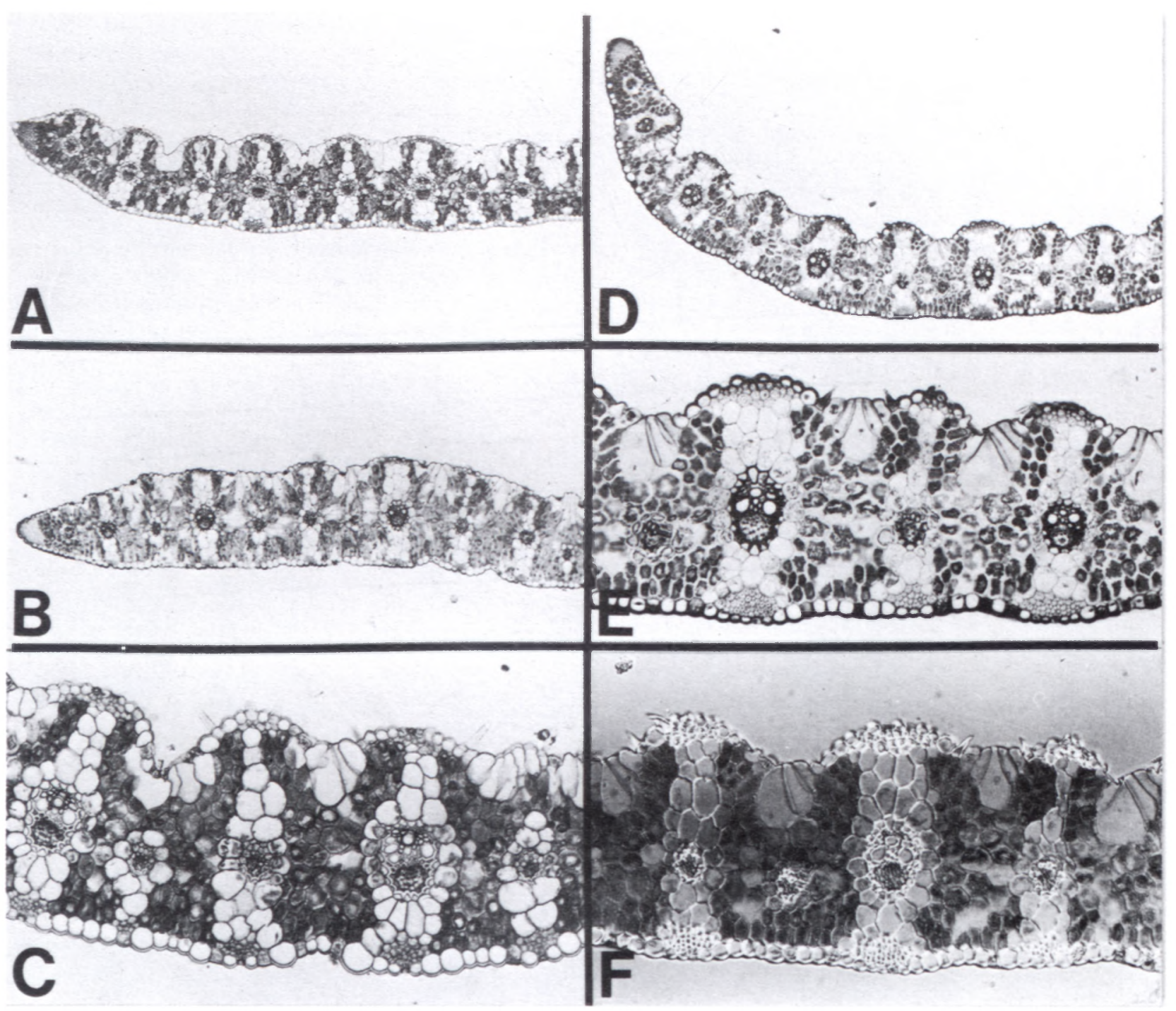

FIGURE 5. - Transverse sections of Group 3 Chaetobromus specimens. A, outline, Ellis 2358, $\times 100$. B, outline and leaf margin, Ellis $1691, \times 100$. C, anatomical detail of chlorenchyma and vascular bundles, Ellis 2357, X 250. D-F, Ellis 1696: D, slightly inrolled outline, $\times 100 ; \mathrm{E}$, chloroplast distribution in bundle sheath and chlorenchyma cells, $\times 250 ; \mathrm{F}$, interference contrast showing chloroplast and bundle sheath cell shape, $\times 250$.

\section{DISCUSSION}

\section{Subfamilial and tribal classification}

The results of this study confirm and expand the findings of De Wet (1956) and Watson et al. (1986) who reported a 'festucoid' transectional anatomy and a panicoid abaxial epidermis for Chaetobromus. The abaxial epidermis is not pooid in several respects such as the possession of microhairs, dumbbell-shaped silica bodies and domeshaped stomata, and as a result, pooid relationships can be discounted. Microhairs are unknown in pooid grasses and dumbbell-shaped silica bodies are very rare (Watson et al. 1985). Watson et al. (1986) did not observe abaxial microhairs on Chaetobromus but their presence is confirmed here although they are rare and appear to be absent on those specimens assigned to groups 3 and 4 . Panicoid type dumbbell-shaped silica bodies are common although the nodular type of pooid body was sometimes present. This confirms the observations of Watson et al. (1986). The pooid type of stomata, in which the guard cells overlap the interstomatal cells (Watson \& Johnston 1978), do not appear to occur in Chaetobromus as reported by Watson et al. (1986). Instead the guard cells are flush with the interstomatals and the subsidiary cells are domeshaped. This is typical of the panicoid type and not pooid where the subsidiaries are typically parallel-sided.

The transectional anatomy of Chaetobromus, on the other hand, can be considered to be of the pooid type. The outer bundle sheath cells are non-Kranz and do not possess specialized chloroplasts and have thin cell walls. The chlorenchyma cells are large parenchymatous cells usually diffusely arranged, often tending to the radiate condition. The genus is undoubtedly $C_{3}$ as suggested by Watson et al. (1986) although this has yet to be confirmed physiologically.

This combination of pooid transectional anatomy with a panicoid type of epidermis is typical of the Arundinoideae. The leaf anatomy, therefore, supports arundinoid affinities for Chaetobromus and is in full agreement with the classification of the genus in the Arundineae (Clayton \& Renvoize 1986).

Certain aspects of the chlorenchyma of Chaetobromus deserve further comment. As noted by Watson et al. (1986), the lateral cell count is rather low, from 3-5 


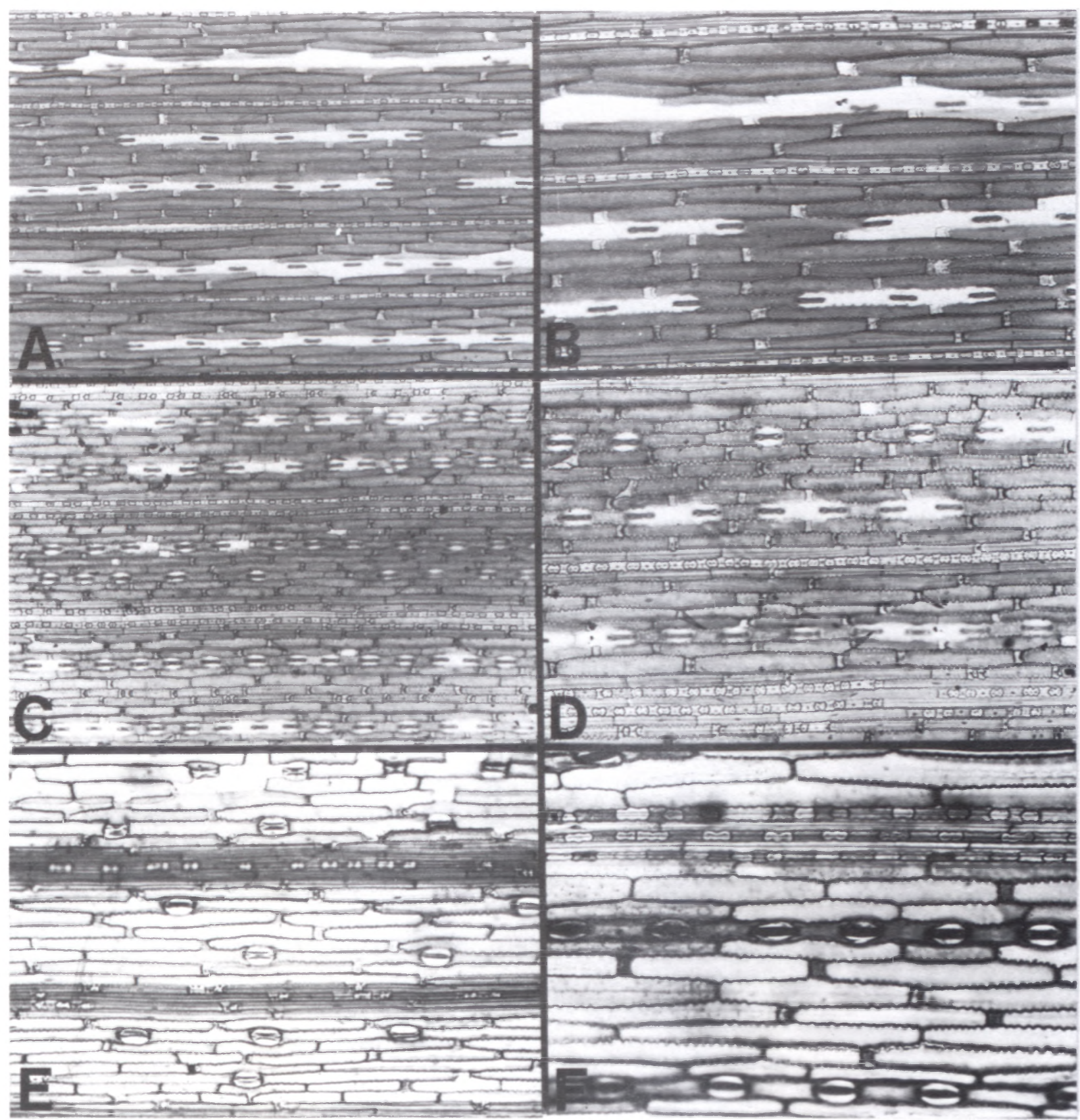

FIGURE 6.- Abaxial epidermal structure of Chaetobromus specimens of Group 3. A-B, Ellis 2357: A, costal and intercostal zone distribution, X 160; B, fusiform long cells and differential staining of intercostal long cells, $\times 250$. C-D, Ellis 2358: C, costal and intercostal zones, $\times 160$; D, costal and intercostal silica bodies and short intercostal hooks, $\times 250$. E, epidermal pattern, Ellis 1696, X 160. F, subsidiary cell and silica body shape, Ellis $692, \times 400$.

cells, which is unusual in a $\mathrm{C}_{3}$ plant. The chlorenchyma arrangement may also tend to the radial type of arrangement although more than one layer of radiating cells is always present. This chlorenchyma arrangement resembles that of Dregeochloa pumila (Nees) Conert (Ellis 1977), another danthonioid from the winter rainfall coastal areas of the southern Namib Desert. Merxmuellera rangei (Pilg.) Conert appears to represent the extreme of this type of development (Ellis 1982). The vegetation of this area is dominated by succulents and the chlorenchyma of these associated grasses is reminiscent of that of CAM plants, particularly the large size of the cells, their particular radial type of arrangement, the persistent nuclei, large vacuoles and the refractive nature of the chloroplasts under interference contrast illumination. The CAM photosynthetic pathway is unknown in the Poaceae but, if it does occur, these grasses appear to be the most likely candidates. Their photosynthetic physiology deserves investigation as it may demonstrate the presence of CAM in the grass family.

\section{Differences between the species of Chaetobromus}

The basic anatomical differences between the four species or groups in the genus are listed in Table 1. These are usually not discrete differences and they often intergrade between the groups. However, they do give an indication of the anatomical tendencies evident within the genus. 


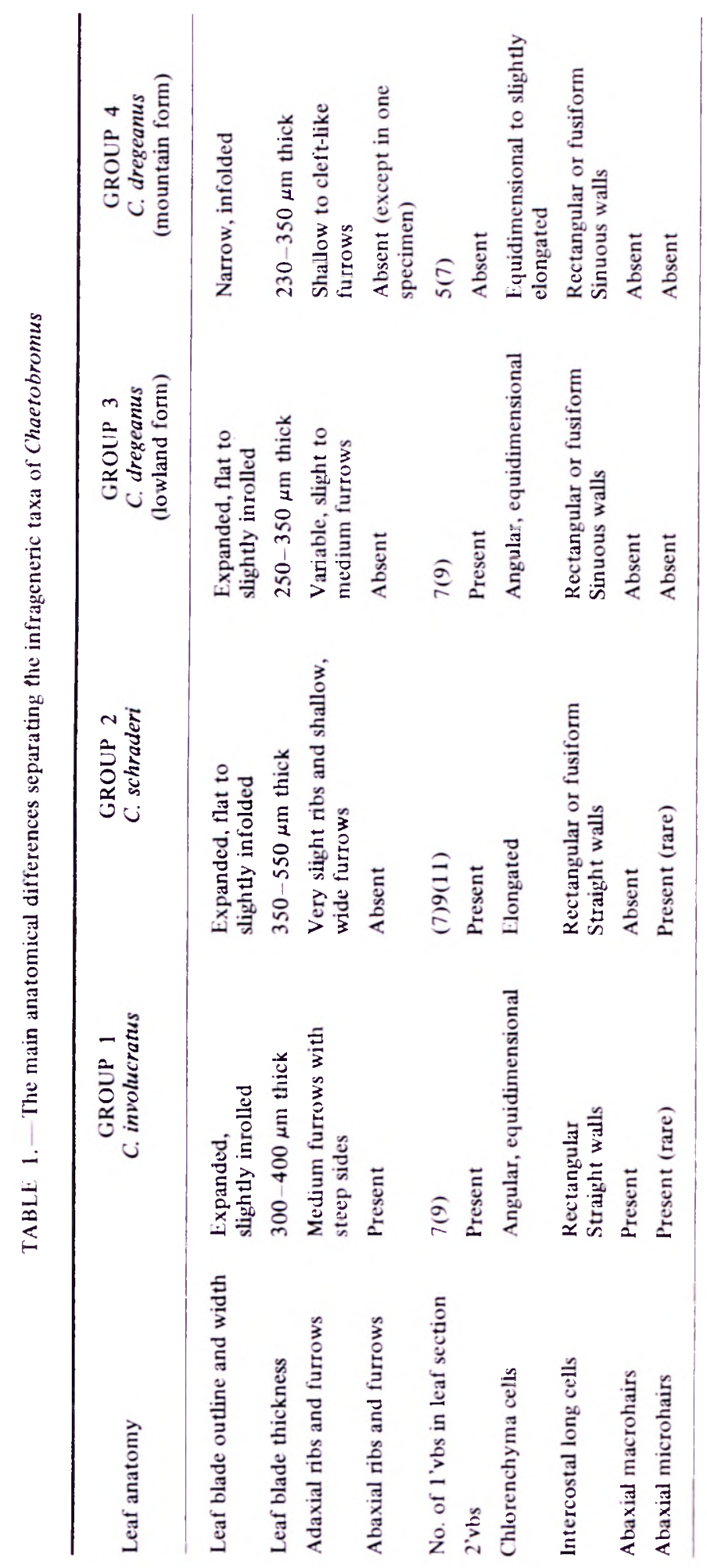


Group 1. Chaetobromus involucratus

\section{Anatomy}

The leaf blades are expanded but tend to roll inwards from both margins when desiccated. The well developed adaxial ribs and steep-sided furrows (Figure 1D \& F) may be associated with this inrolling mechanism. The blades are of intermediate thickness and width and usually contain 7 first order vascular bundles. The chlorenchyma cells are angular to equidimensional and not elongated as in Group 2.

The abaxial macrohairs are diagnostic for this group (Figures 2A-D, 9A, B, 10). Rectangular long cells without sinuous walls and the presence of microhairs (although rare) characterize the epidermis of this group. These microhairs have tapering distal cells which may be equal to or much shorter than the basal cell (Figure 9D).

The diagnostic abaxial macrohairs are not always produced on all leaves or on all plants. Chippindall (1955) considers these hairs to be deciduous as the older leaves appear to become glabrous. The epidermal anatomy confirms that their bases are only superficial and are not inserted between the epidermal cells. Instead they are attached to a small, raised intercostal short cell (Figure 10) which possibly acts as a hinge mechanism. On leaves with few or no hairs, however, there is no evidence of these short cells, or of the slight disruption in the intercostal long cell pattern caused by these bases (Figure 2B). This evidence appears to indicate that these hairs are not deciduous but that their presence is variable, either temporally or spatially.

The function of these hairs is unknown but, as macrohairs or prickles also occur on other perennial grasses from this fog belt, they may help in trapping moisture from the regular sea mists. Examples are Dregeochloa pumila (Ellis 1977) and Centropodia glauca (Nees) T.A. Cope (Ellis 1984).

\section{Morphology and ecology}

Found in loose windblown sand and unstabilized coastal dunes of the Strandveld of Namaqualand. Particularly common in the north from Hondeklip Bay to Alexander Bay but extending as far southward as St Helena Bay (Ellis 703). The rainfall of this region is very low, 50$150 \mathrm{~mm}$ per annum mainly in winter, but it is subject to frequent sea mists. The vegetation is a sparse succulent scrub and the substrate is loose and sandy.

Populations of this taxon are exceedingly variable in vegetative morphology, with each individual plant differing in size, foliage colour and growth form. Plants are generally erect tufts up to $0,3 \mathrm{~m}$ high with the leaves being borne all the way up the culms. The inflorescences are not well exserted. Sometimes the plants are basally tufted but this appears to be in response to grazing. Rhizomes are not prominent except in these basally tufted specimens. The roots often are enclosed in a prominent rhizosphere of sand grains.

The leaf blades are expanded to slightly inrolled and are densely hairy with soft, silky, appressed hairs on the abaxial or both surfaces. This is particularly the case when the leaves are young but, according to Chippindall (1955), they become almost glabrous when older. This is, however, not supported by the available anatomical evidence. There is also a definite decrease in the degree of pubescence southwards from the Orange River and the specimen from St Helena Bay has only a few marginal hairs. However, specimens from the north may also have few hairs.

The Group 1 specimens grade into the Group 3 type from St Helena Bay southwards and their distribution is sympatric between St Helena and Elands Bay. South of this area sea mists decrease in relative importance and frequency and this may account for the loss of the macrohairs.

The morphology of the Group 1 plants conforms closely to the description of $C$. involucratus (Chippindall 1955) and most specimens assigned to this group were identified as such. However, a few were identified as $C$. schraderi because these usually had very few macrohairs as in Ellis 703 and 2176 (Figure 1E \& F) but the blade of Ellis 2175, which was examined anatomically, had a dense pubescence (Figure 2A \& B).

Group 1 is therefore virtually synonymous with C. involucratus and is reasonably distinct from the other taxa. It is distinguished morphologically by the presence of the diagnostic hairs and it also occupies a specialized habitat. However, it does intergrade with both Groups 2 and 3 , both in morphology and ecology, and they cannot always be clearly separated.

\section{Group 2. Chaetobromus schraderi}

\section{Anatomy}

All specimens have expanded but flat leaf blades which appear to fold in response to moisture stress. This contrasts to the inrolling of the leaves of Groups $1 \& 3$. The adaxial ribs and furrows are also poorly developed (Figures 3E \& F) and this may be associated with the infolding rather than an inrolling mechanism. The leaf blades are thicker than in any of the other groups and may be up to $550 \mu \mathrm{m}$ thick. The leaves also tend to be wider with an average of 9 first order bundles. The chlorenchyma is distinctive with large, elongated or rounded cells arranged in a radiate manner; the nuclei tend to be persistent and the chloroplasts may be refractive. This chlorenchyma structure resembles that of some liliaceous CAM plants and Group 2 plants may exhibit modifications of the $\mathrm{C}_{3}$ photosynthetic pathway.

Macrohairs are absent and the long cells have straight walls and are usually rectangular as in Group 1. However, they do vary and may be fusiform in shape (Figure 4D). Microhairs are present although uncommon and the distal cell does not taper to a pointed apex (Figure $9 \mathrm{H}$ ).

The transverse sections of the Group 2 plants are distinctive but the abaxial epidermis resembles that of Group 1 more than that of the other two anatomical groups. The main differences between Groups 1 and 2 are the absence of macrohairs and the shape of the microhairs. 


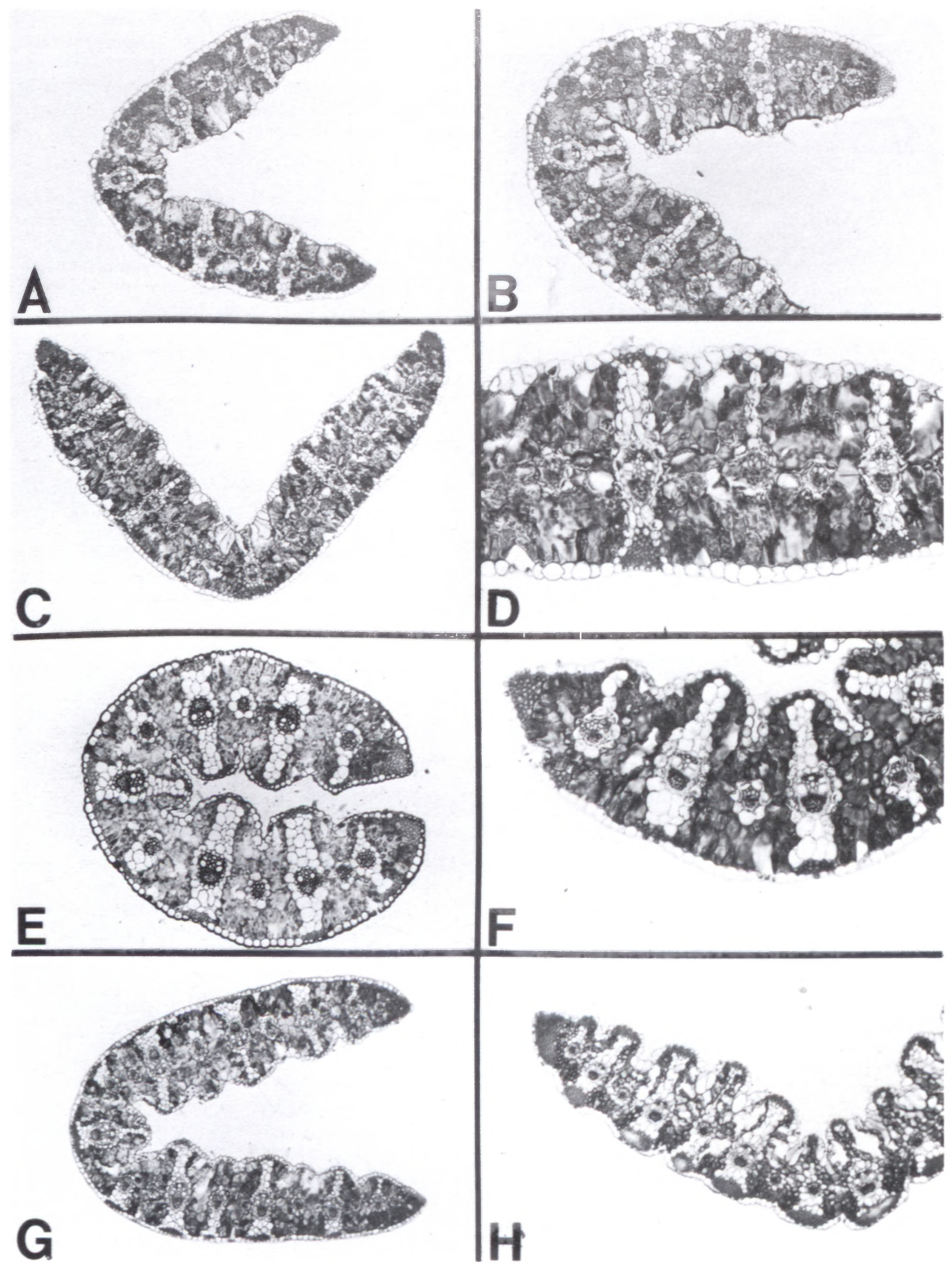

FIGURE 7.- Transections of Group 4 specimens of Chaetobromus. A, narrow, infolded leaf blade, Ellis 2424, $\times 100$. B, vascular bundle arrangement, interference contrast, Ellis 2423, X 160. C-D, Ellis 2467: C, infolded leaf, X 100; D, detail of chloroplasts in chlorenchyma and bundle sheath cells, $\times 250$. E-F, Ellis 2450 : E, inrolled, setaceous outline, $\times 160 ; \mathrm{F}$, vascular bundles showing low lateral cell count, $\times 250$. G, outline of specimen from mountain fynbos on sandstone, Elis $2457, \times 100$. H, outline of specimen from Succulent Karoo, Ellis 2426, X 100. 


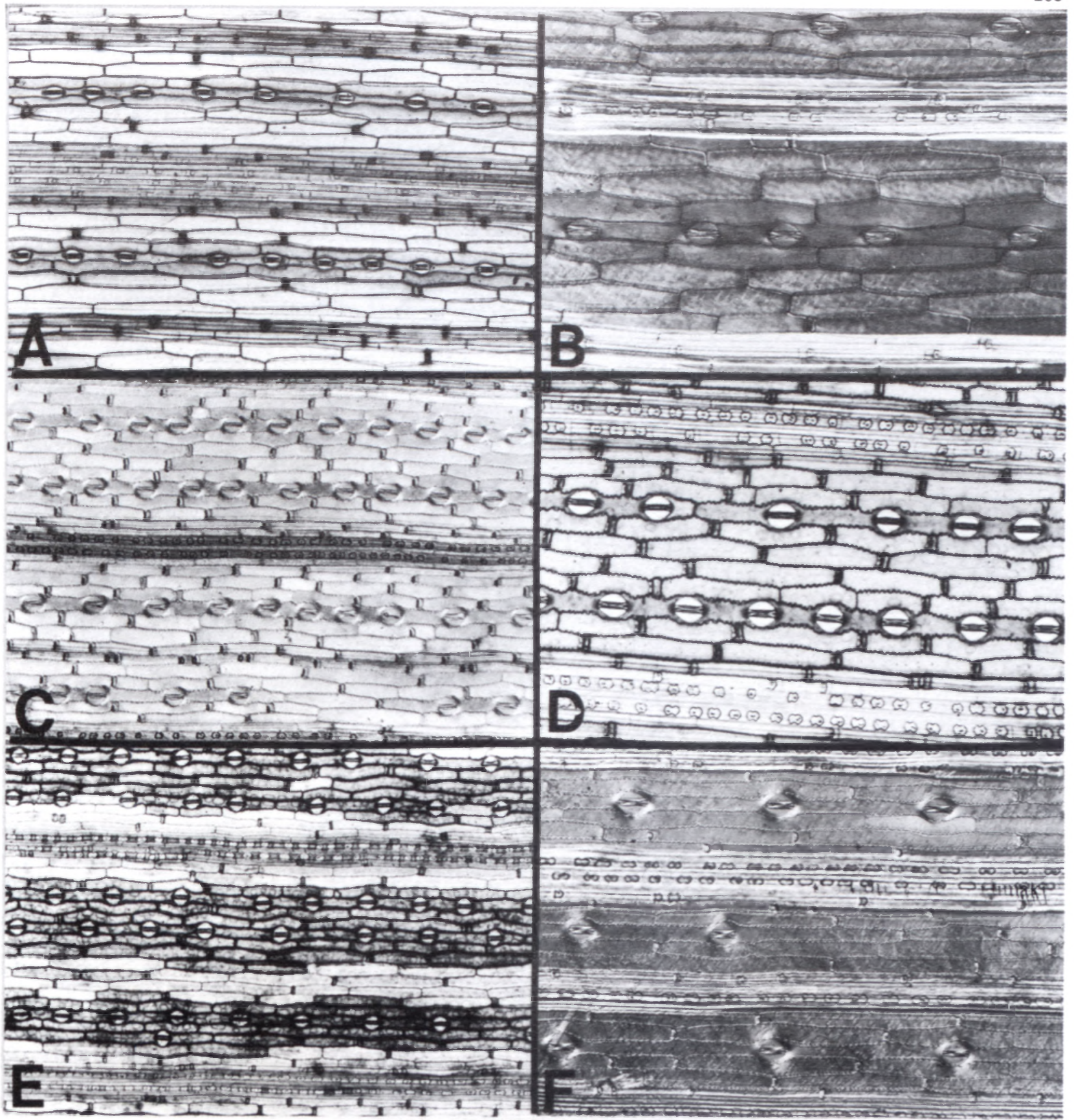

FIGURE 8. - Abaxial epidermis of Group 4 Chaetobromus specimens. A-B, Ellis 2424: A, epidermal zonation, X 160; B, de tail of fusiform long cells and stomata, interference contrast, $\times 250$. C-D, Ellis 2457: C, interference contrast showing numerous stomata in regular files, $\times 160$; D, detail of stomata, intercostal long cells and costal cells (note absence of microhairs), $\times 250$. E, epidermal pattern with differential staining, Ellis $2467, \times 160$. F, stomata and silica bodies, interference contrast, Ellis $2422, \times 250$.

\section{Morphology and ecology}

This group is found in the Namaqualand Coast Belt of the Succulent Karoo and in Namaqualand Broken Veld. It appears to prefer heavier stony soils, often between granite rocks in the mountains of Namaqualand. It also occurs on the sand of the coastal plain but not on unstabilized sand, the habitat characteristic of Group 1 The specimens Ellis 5071 (Group 1) and Ellis 5073 (Group 2) are informative in this regard as they were found growing in close proximity to each other but differ considerably in epidermal structure (Figure 9AH). Ellis 5073 was rooted in gravelly soil between granite boulders which had subsequently been covered by fine, loose wind-blown sand in which Ellis 5071 was growing. Group 2 plants are most common along roadside verges where they are protected from grazing.
The distribution area extends from the Richtersveld in the north to the Vanrhynsdorp District in the south. This area receives a sparse winter rainfall varying between 50-300 mm per annum with fog decreasing in importance The vegetation is dominated by succulents.

Populations of Group 2 plants are very variable with individual plants exhibiting different growth forms and vegetative morphology. Generally they are robust, tall plants up to $0,9 \mathrm{~m}$ tall. The leaves are not basally concentrated but are cauline. These leaves are long and expanded, up to $10 \mathrm{~mm}$ wide and glabrous. The leaf sheaths may be hairy and the adaxial surface has short prickles (Figure 4F). The rhizomes are short but well developed and inclined upwards resulting in loosely caespitose plants. The roots are tough and corky and a rhizosphere is seldom developed. 


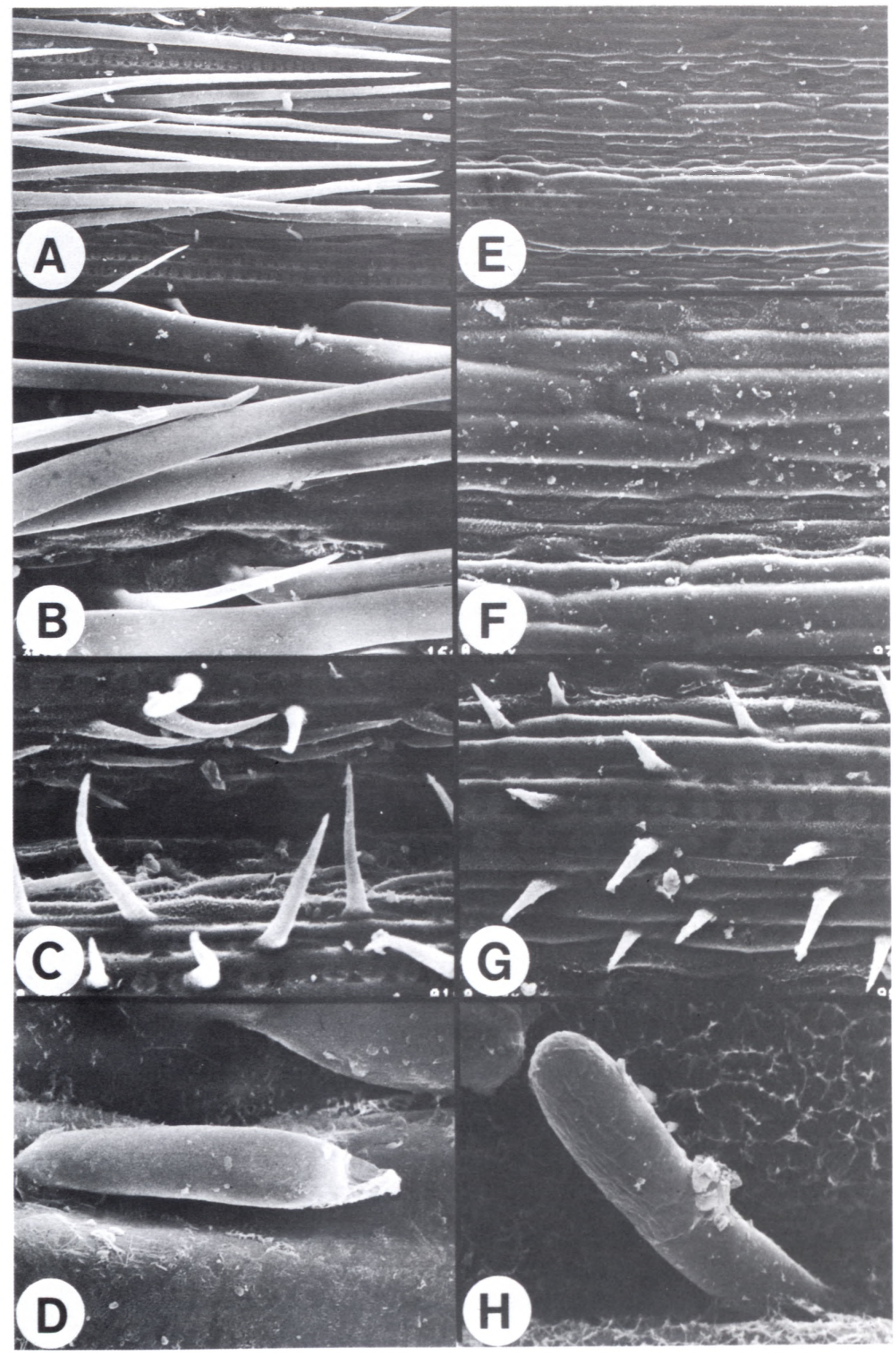


The name applied to most specimens of this group is C. schraderi although two specimens were identified as C. dregeanus. Morphologically and ecologically this group is not well separated from $C$. involucratus (Group 1) and appears to be an inland segregate of that species. Chippindall (1955) considered $C$. schraderi to be a sand dune species found south of Saldanha Bay to Table Bay. This distribution corresponds with the Group 3 specimens of the present study, all of which were determined as $C$. dregeanus. The possibility therefore exists that these names have been misapplied.

Although no consistent and reliable vegetative and ecological diagnostic characters appear to distinguish C. involucratus (Group 1) from C. schraderi (Group 2), leaf anatomy reveals differences which may justify the upholding of these two taxa.

\section{Group 3. Chaetobromus dregeanus (lowland form)}

\section{Anatomy}

The leaf blades are flattened to slightly inrolled with adaxial ribs and furrows and are generally thinner than in either Group 1 or 2 . The chlorenchyma cells resemble those of Group 1, being angular and equidimensional (Figures 5C \& F) and not as large and elongated as in Group 2. The transectional anatomy is, therefore, very similar to that of Group 1.

The abaxial epidermis, on the other hand, differs considerably from that of Group 1. Macrohairs and microhairs are absent and the long cells are sinuous. This epidermal structure resembles that of Group 4.

\section{Morphology and ecology}

Only a small sample of this taxon was studied but all specimens were collected in the southern Strandveld, from Elands Bay southwards to Table Bay, in the Dense Strandveld Scrub variation of this veld type (Acocks $1975)$. Winter rainfall is higher $(200-300 \mathrm{~mm})$ than further north and fog is infrequent. The vegetation consists of a dense, dwarf, semi-succulent scrub, about $1 \mathrm{~m}$ tall. The sand is stabilized, the dunes being well vegetated and the soil has a high humus content. This is clearly evident on the roots which are black in colour.

The plants form loose, diffuse tufts up to $0,4 \mathrm{~m}$ high. The culms are not basally concentrated but dispersed and linked by rhizomes or even stolons up to $0,25 \mathrm{~m}$ long. Scattered culms, therefore, protrude through the dense scrubby vegetation. The leaves are borne up the culms and are expanded to slightly inrolled but glabrous.

This group appears to represent a southward extension of $C$. involucratus (Group 1) which has become adapted to the absence of fog, a denser vegetation and stabilized,

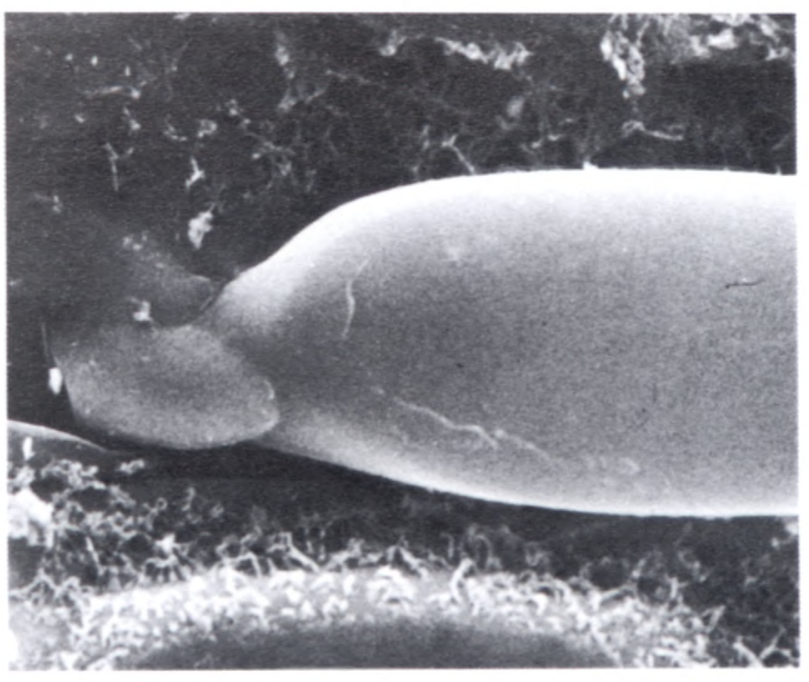

FIGURE 10. - Base and epidermal attachment of abaxial macrohair of Group 1, Chaetobromus involucratus, Ellis 5071, $\times 660$.

humic sand. Unexpectedly the identification of the voucher specimens does not reflect this relationship as they were all assigned to $C$. dregeanus, a species which does not appear to be closely linked to $C$. involucratus. Judging by the identification, Group 3 is therefore considered to be merely a lowland form of $C$ dregeanus. This view, however, is in conflict with the evidence presented here. Chippindall (1955) considered C. schraderi to occur in these southern Strandveld areas and this taxon may, therefore, actually be $C$. schraderi. The typification of the names applied to these Chaetobromus taxa is required to resolve these nomenclatural difficulties.

\section{Group 4. Chaetobromus dregeanus (mountain form)}

\section{Anatomy}

The transectional anatomy of this group is diagnostic, the leaves being narrow and strongly infolded or inrolled. In some cases this reduction resembles the permanently infolded, setaceous condition (Figure 7E). Associated with this narrowing of the leaf blade is a reduction in the number of first order vascular bundles to 5 and the loss of the second order bundles. The cleft-like adaxial furrows may also result from the extreme infolding exhibited by some specimens of this group (Figure 7E \& F).

The epidermis bears a close resemblance to that of Group 3 due to the sinuous long cell walls and the absence of microhairs and macrohairs.

\section{Morphology and ecology}

This group includes all those Chaetobromus specimens from the inland, mountainous areas of the western

FIGURE 9.- SEM micrographs showing the abaxial and adaxial epidermal structure of specimens of Choetobromus involucratus and $C$. schraderi collected at the same locality. A-D, Ellis 5071, Group 1: A, abaxial epidermis showing dense pubescence of intercostal macrohairs, $\times 66$; $\mathrm{B}$, detail of macrohairs showing superficial bases, $\times 204$; , adaxial epidermis with prickle hairs on ribs which differ in size and base structure from the abaxial macrohairs, $X 204$; D, abaxial microhair with very short, tapering distal cell, $\times$ 900. E-H, Ellis 5073, Group 2: E, abaxial epidermis lacking macrohairs, X 66; F, detail of inflated intercostal long cells overarching the slightly sunken stomata, X 204; G, adaxial epidermal ribs with prickle hairs with short barbs, $\times 204$; H, adaxial microhair showing basal and distal cells of equal length and the distal cell with a blunt apex, $X 1320$. 
Cape. Most representatives of this group were collected in the Western Mountain Karoo, particularly in the lower or semi-succulent form of this veld type (Acocks 1975) from the Loeriesfontein, Calvinia and Sutherland Districts. These areas range in altitude from $600-1000 \mathrm{~m}$ above sea level and receive $150 \mathrm{~mm}$ and less of rain, mostly in winter. They are dry, heavily overgrazed areas with a sparse karroid vegetation. Nowadays Chaetobromus is only found in protected sites between rocks and under bushes but it may formerly have been much more common, extending further eastwards as far as Fraserburg and even Hanover (Chippindall 1955).

A few other specimens with narrow, infolded leaves have also been included in this group although they differ slightly in leaf anatomy and occur in other veld types. The sample studied is too small to draw meaningful conclusions but these may deserve recognition as separate groups. Ellis 2457 is the only specimen studied which originated in Mountain Fynbos on soil derived from Table Mountain Sandstone. The anatomy differs little from that characteristic of this group although abaxial stomata are particularly common (Figures 7G, 8C \& D). Ellis 2426 is the other specimen assigned to this group on anatomical grounds but it was collected in the Succulent Karoo on very stony soil. This specimen is characterized by having well developed sclerenchyma strands and adaxial ribs and furrows (Figure $7 \mathrm{H}$ ).

Plants of this group are characteristically densely tufted with basally concentrated foliage, cauline leaves being absent. The leaves are rolled or folded, narrow to filiform ( $1-3 \mathrm{~mm}$ wide), and glabrous. The inflorescences are exserted well above the foliage. Bases are dense, compact to almost flabellate with short rhizomes. Lateral spreading rhizomes are seldom present and then only up to $0,1 \mathrm{~m}$ long.

All voucher specimens were determined as $C$. dregeanus and this group appears to represent a mountain form of this species. A different concept of $C$. dregeanus appears to have been applied by Chippindall (1955) as she also included specimens with tall culms with cauline leaves from the Namaqualand coastal plain. In the present study this latter type of specimen has been grouped with $C$. schraderi in Group 2. This nomenclatural problem must be resolved before the correct names for these taxa can be applied. Group 4 is nevertheless, morphologically, ecologically and anatomically distinct and separate from the other three groups.

\section{CONCLUSIONS}

The 33 Chaetobromus specimens examined in this study can be grouped into four anatomical entities, each possessing a characteristic combination of attributes; most groups also have additional diagnostic anatomical characters. Thus Group 1 has abaxial macrohairs and tapering microhairs; Group 2 has truncated microhairs, thick, flat or slightly infolded blades and distinct chloren. chyma; Group 3 is similar to Group 1 but lacks macrohairs and microhairs and has sinuous long cell walls, and Group 4 has setaceous leaves without second order vascular bundles. Other characters are shared by pairs of groups. Groups 1 and 2 both have microhairs and straightwalled long cells whereas Groups 3 and 4 do not have microhairs and the long cells have sinuous walls. Groups 1 and 3 both have inrolled leaves whereas Groups 2 and 4 tend to have infolded leaves.

Discontinuities are therefore not clear between the four groups and they tend to intergrade into one another in a reticulate manner. The groups are not discrete entities but merely seem to reflect evolutionary trends. A similar situation is also evident in the ecological preferences and vegetative and spikelet morphology. For these reasons it is extremely difficult to reliably and consistently define species and the recommendations of this study are to uphold only a single species in the genus with four reasonably clear subspecific taxa. These appear to represent ecotypes, each occurring in a specific habitat: the differing ecological parameters appear to be reflected in the anatomy and vegetative morphology but no consistent spikelet differences appear to be associated with these environmental differences.

Populations of Chaetobromus plants in the field are exceedingly variable, even within limited populations, with each plant often differing in vegetative morphology. This appears to be the case even in homogeneous habitats where all the individuals appear to be of equal age and are subject to the same environmental constraints. In less uniform habitats, such as rocky outcrops where soil depth, moisture availability and insolation can vary over very short distances, this variation becomes even more exaggerated, particularly if the area is also subject to grazing. This type of variation suggests that genetic differences exist between individuals even in small populations. This appears to be confirmed by chromosome numbers of $n=12,24$ and 27 for different specimens of Chaetobromus as well as indications of karyotype evolution in the form of paracentric inversions (Spies \& Du Plessis 1988).

Clearly the taxonomy of this genus requires further biosystematic study including detailed fieldwork, cytogenetics and even transplant experiments. This detailed study is fully justified as Chaetobromus appears to possess excellent potential as a fodder grass. With correct veld management based on knowledge of the reproductive biology and vegetative ontogeny of the genus this grass could help considerably in enhancing the range quality and carrying capacity of the Succulent Karoo Biome.

\section{ACK NOW LI DGEMENTS}

Mrs H. Ebertsohn is gratefully thanked for technical assistance, Mrs A. Romanowski for the photography, Mrs S. Perold for the electron microscopy, and Mrs M. van der Merwe for typing the manuscript.

\section{REFERENCES}

ACOCKS, J.P.H. 1975. Veld Types of South Africa, 2nd edn. Memoirs of the Botanical Survey of South A frica No. 40 $1-127$.

BREAKWELL, E. 1914. A study of the leaf anatomy of some native species of the genus Andropogon (Gramineae). Proceedings of the Linnean Society of New South W'ales 39 $385-394$

CHIPPINDALL, L.K.A. 1955. In D. Meredith, The grasses and pastures of South Africa. CNA, Johannesburg. 
CLAYTON, W.D. \& RENVOIZE, S. 1986. Genera graminum, grasses of the World. Kew Bulletin, Addition Series XIII: $1-389$

DE WET, J.M.J. 1956. Leaf anatomy and phylogeny in the tribe Danthonieae. American Joumal of Botany 43: 175-182.

DU PLESSIS, H. \& SPIES, J.J. 1988. Chromosome studies on African plants. 8. Bothalia 18: 119-122.

ELLIS, R.P. 1976. A procedure for standardizing comparative leaf anatomy in the Poaceae. 1. The leaf blade as viewed in transverse section. Bothalio 12: 65-109.

ELLIS, R.P. 1977. Leaf anatomy of the South African Danthonieae (Poaceae). 1. The genus Dregeochloa Bothalia 12: $209-213$.

ELLIS, R.P. 1979. A procedure for standardizing comparative leaf anatomy in the Poaceae. 2. The epidermis as seen in surface view. Bothalia 12:641-672.

ELLIS, R.P. 1982. Leaf anatomy of the South African Danthonieae (Poaceae). VII. Merxmuellera dura and $M$ rangei Bothalia 14: 95-99.

ELLIS, R.P. 1984. Leaf anatomy of the South African Danthonieae (Poaceae). IX. Asthenatherum glaucum. Bothalia 15: $153-159$.
FEDER, N.\& O'BRIEN, O.P. 1968. Plant microtechnique: some principles and new methods. American Joumal of Botany 55: $123-142$.

JOHANSEN, D.A. 1940. Plant microtechnique. McGraw-Hill New York.

METCALFE, C.R. 1960. Anatomy of the Monocotyledons. 1. Gramineae. Clarendon Press, Oxford.

SMOOK, L. \& GIBBS RUSSELL, G.E. 1985. Poaceae. In G.E. Gibbs Russell, C. Reid, J, van Rooy \& L. Smook, List of species of southern African plants, edn 2, part 1. Memoirs of the Botanical Survey of South A frica No. 51: $1-152$.

WATSON, L., CLIFFORD, H.T. \& DALIWITZ, M.J. 1985. The classification of Poaceae: subfamilies and supertribes. Australian Journal of Botany 33: 433-484.

WATSON, L., DALLWITZ, M.J. \& JOHNSTON, C.R. 1986. Grass genera of the world: 728 detailed descriptions from an automated database. Australian Journal of Botany 34 $223-230$.

WATSON, L. \& JOHNSTON, C.R. 1978. Taxonomic variation in stomatal insertion among grass leaves. Australian Journal of Botany 26: 235-238. 